$\checkmark$ details of the new arrangements rather than passing any hasty judgement.

But others have greeted Cadogan's statement with scepticism, pointing out that there is little in the DTI's recent track record to suggest it is genuinely committed to longterm fundamental research. Many have been quick to point out, for example, that since the publication of the white paper on science in May 1993, the research and development budget of the department has fallen substantially.

Admittedly, much of the reduction has taken place in technology development programmes, rather than basic research, and the DTI has built strong links with various research councils, in particular the Engineering and Physical Sciences Research Council. But the department, under Heseltine's leadership, also abolished the post of chief scientific adviser shortly after the publication of the white paper.

"We note that the OST is going to be ring-fenced within the DTI, but it will be a ring fence in the middle of a lion compound," says Alun Jones, chief executive of the Institute of Physics. "It makes sense for science to be linked closer to technology and industry. But we are disappointed that it appears to have moved lower down the government's priorities."

Unsurprisingly, the decision to move the OST into the DTI has come under fierce criticism from the opposition Labour Party, which itself considered - but rejected proposing such a move as part of its own science policy two years ago. John Battle, Labour's science spokesman, says that the move represents "the demotion of science and technology".

Meanwhile in the scientific community itself, perhaps the greatest immediate concern is over the future of governmentfunded laboratories owned and run by the research councils.

Although moves to 'privatize' organizations such as the Medical Research Council's Laboratory of Molecular Biology in Cambridge had previously been headed off, the appointment of Heseltine, a keen advocate of this strategy, suggests that such proposals are likely to come in for renewed attention.

David Dickson

$D$ hearings as well as a visit to the United States, of the implications of human genetics. Its report, due next week, is expected to contain a wide sweep of recommendations, from amendments to patent legislation limiting the scope of patents on human genes, to the need for regulations on the use of genetic information by insurance companies.

If Parliament follows its established rules of procedures - and rejects moves currently under consideration to depart from its accepted practice - all such issues will now be dealt with by a committee whose main brief will be to look at all the activities of the DTI, ranging

\title{
US may drop federal support for families of researchers
}

San Francisco. The Clinton administration has proposed eliminating rules that allow research universities to put the relatives of faculty members through college at the taxpayer's expense. Universities say that they need the benefit in order to attract and retain top researchers. But critics say the government gets nothing in return.

According to the General Accounting Office (GAO) - the investigatory arm of Congress - between 1991 to 1993, four top US research universities charged $\$ 17$ million to the government for the tuition costs of faculty family members. The GAO studied five institutions: the Massachusetts Institute of Technology, Stanford University, the University of California, John Hopkins University and the University of Chicago.

MIT charged the highest portion - 56 per cent - of its programme costs of $\$ 12,566$ per family member to federal research contracts and grants. The University of Chicago, which has the most generous programme, charged the least, with 15 percent of its $\$ 16,842$ in costs repaid by the government. The University of California asked for no reimbursement; it does not provide financial assistance to relatives of faculty, on the grounds that its tuition charges are comparatively low.

The GAO found that education benefits had been a long-standing tradition at the universities since the $1960 \mathrm{~s}$. The practice was initially intended to help overcome a shortage of scientists, engineers and other researchers, says Charles Thompson, assistant director in acquisition policy, technology and competitiveness issues for the GAO. "Today, the environment may be different," he adds, pointing out that the GAO did not recommend that the programme should be suspended - merely that it should be examined more closely.

Universities say the benefit remains an important recruiting tool as the salaries they offer continue to lag far behind those in the

from the management of pension funds to the operation of frontier customs. Furthermore, any questions to ministers on science-related topics could now end up being handled by a junior minister within the DTI.

Both moves have already raised concern among professional bodies such as the Royal Society of Chemistry which have grown to appreciate the opportunity that the existence of the science select committee - as well as that of a protected 'science questions' time - has provided them and others to air opinions and grievances in a formal parliamentary setting.

D. D. commercial sector. They argue that the government should allow universities to manage their overall compensation programmes, as long as the total amount of money is reasonable. Cutting the government reimbursement policy would only force them to offer higher salaries which would then be charged back to grants, universities add.

But the Clinton administration, after one look at the GAO report, proposed the reimbursement be slashed. "It was our judgment there wasn't any real benefit coming back to the government itself," says Lawrence Haas, associate director for communications at the Office of Management and Budget. He said universities may need the benefit, but that doesn't mean the government should have to pay for it.

Haas said his office would carefully consider the 200 or so responses it had received and was planning to issue a final decision within a couple of months. Sally Lehrman

\section{France urged to set up genetics network}

Paris. France's healthcare system has failed to adapt adequately to advances in genetics research, and urgently needs to create a national network of specialized genetic clinics staffed by physicians trained in medical genetics.

These are the main conclusions of a report submitted last week to Elisabeth Hubert, the minister of health, by JeanFrançois Mattei, who is both head of the Paediatrics and Medical Genetics Department at the Timone hospital in Marseille, and a member of the National Assembly (UDF, Bouches-du-Rhône).

The report claims that consultations in clinical genetics are haphazard, and are often only available from research groups at major teaching hospitals. Indeed, Mattei points out that medical genetics was not recognised as a speciality until a law making it one was passed earlier this year.

To address these deficiencies, Mattei recommends that one clinical genetics centre be set up for every 300,000 inhabitants. Each centre would include a clinical geneticist, a cytologist, and a molecular biologist.

Mattei argues that such a network will also help to regulate the development of medical genetics, and in particular avoid the setting up of private centres offering genetic testing. Support for his recommendations is likely to come from the government. Alain Juppé, the new prime minister, called for a national programme in medical genetics in a speech made shortly after his nomination in May.

Declan Butler 